\title{
Some Novel Penta-Coordinated Ethylaluminium(III) Complexes with Aminoalcohols: Synthetic, Spectoscopic and Structural Aspects of $\left[\mathrm{Et}_{2} \mathrm{AlL}\right]$ and $\left[\mathrm{EtAlL} \mathrm{L}_{2}\right]$
}

\author{
Amit K. Jain, Anjali Gupta, Rakest· Bohra* and Ram C. Mehrotra \\ Department of Chemistry, University of Rajasthan, Jaipur-302004, India \\ rkbohra@satyam.net.in
}

\begin{abstract}
A series of monoethyl and diethylaluminium(III) complexes of the types $E t_{2} A l\left\{O-R-N R^{\prime} R^{2}\right\}$ or EtAl $\{O-$ $\left.\mathrm{R}-\mathrm{NR}^{1} \mathrm{R}^{2}\right\}\left[\mathrm{R}=-\mathrm{CH}_{2}\right)_{2}, \mathrm{R}^{1}=\mathrm{H} ; \mathrm{R}=-\left(\mathrm{CH}_{2}\right)_{3}, \mathrm{R}^{\prime}=\mathrm{R}^{2}=\mathrm{H} ; \mathrm{R}=-\mathrm{CH}_{2} \mathrm{CH}\left(\mathrm{CH}_{2} \mathrm{CH}_{3}\right), \mathrm{R}^{\prime}=\mathrm{R}^{2}=\mathrm{H} ; \mathrm{R}=-$ $\left(\mathrm{CH}_{2}\right)_{3}, \mathrm{R}^{\prime}=\mathrm{H}, \mathrm{R}^{2}=\mathrm{CH}_{3} ; \mathrm{R}=-\left(\mathrm{CH}_{2}\right)_{3}, \mathrm{R}^{1}=\mathrm{R}^{2}=\mathrm{CH}_{3} ; \mathrm{R}=-\mathrm{C}_{6} \mathrm{H}_{4}, \mathrm{R}^{1}=\mathrm{R}^{2}=\mathrm{H}$ ] have been prepared by the reactions of triethylaluminium etherate adduct $\left(\mathrm{Et}_{3} \mathrm{Al}_{\mathrm{Et}} \mathrm{Et}_{2} \mathrm{O}\right)$ with the corresponding aminoalcohols in $1: 1$ and 1:2 molar ratios in diethyl ether. All the above complexes are soluble in common organic solvents. Molecular weight measurements in refluxing benzene exhibit monomeric and dimeric nature for the monoethyl and the diethyl complexes respectively. All these derivatives have been characterized by elemental analysis, $1 \mathrm{R}$ and multinuclear NMR $\left({ }^{1} \mathrm{H},{ }^{13} \mathrm{C}\right.$ and $\left.{ }^{21} \mathrm{Al}\right)$ spectral studies. The ${ }^{21} \mathrm{Al}$ NMR chemical shift values indicate pentacoordination around aluminium(III) atom in both the above types of complexes.
\end{abstract}

\section{INTRODUCTION}

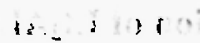

Aluminium alkyls are often used as reagents in organic synthesis and as catalysts in synthetic processes 11/. For a better understanding of their role from the synthetic and catalytical aspects, it is important to predict the coordination ability of aluminium in such types of derivatives. Generally coordination numbers four and six are more common $/ 2-6 /$ as compared to five $/ 7,8 /$ in such compounds.

It has been shown recently /1,9-13/ that aluminium atoms in binuclear metallo-organic complexes usually acquire unsymmetrical structures (Fig. 1) containing aluminium(III) atoms in four- and six-coordination states rather than a symmetrical five-coordinated strucutre.

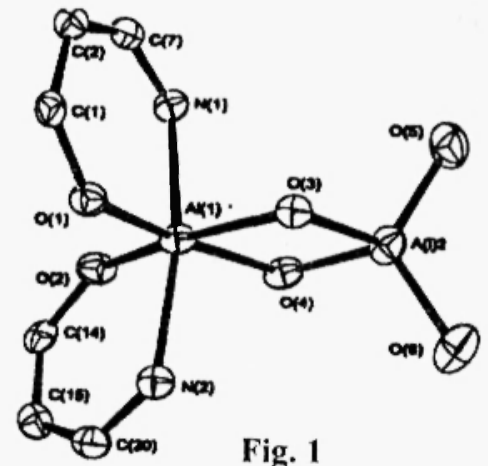


More recently we have also reported what is probably the first known example of a five-coordinated heteroleptic metallo-organic compound of $\mathrm{Al}(\mathrm{III})\left[\left\{\mathrm{C}_{6} \mathrm{H}_{4} \mathrm{O}\left(\mathrm{CH}=\mathrm{NC}_{6} \mathrm{H}_{5}\right)\right\}_{2} \mathrm{Al}\left\{\mathrm{ON}=\mathrm{C}\left(\mathrm{CH}_{3}\right) \mathrm{C}_{4} \mathrm{H}_{3} \mathrm{~S}-2\right\}\right] / 14 /$.

In view of the above it was considered worthwhile to prepare the corresponding five-coordinated organoaluminium(III) complexes by the reaction of triethylaluminium etherate adduct $\left(\mathrm{Et}_{3} \mathrm{Al} \cdot \mathrm{Et}_{2} \mathrm{O}\right)$ with a variety of aminoalcohols, which are of special interest due to the presence of both hydroxyl as well as amino groups.

\section{MATERIALS AND METHODS}

All the complexes described in this investigation were manipulated in a vacuum line or a purified argon atmosphere. The solvents and reagents were purified by conventional techniques. The $\mathrm{Et}_{3} \mathrm{Al} \mathrm{Et} \mathrm{t}_{2} \mathrm{O}$ was synthesized and purified according to literature method /15/. Aminoalcohols were purified by distillation prior to use. Aluminium was estimated gravimetrically as oxinate $/ 16 /$. Microanalyses were carried out on a Perkin Elmer-C, H, N \& S II series 2400 analyzer. The IR spectra were recorded as Nujol mull on a Nicolet Magna-550 spectrometer in the range $4000-400 \mathrm{~cm}^{-1} .{ }^{1} \mathrm{H},{ }^{13} \mathrm{C}$ and ${ }^{27} \mathrm{Al} \mathrm{NMR}$ spectra were recorded in $5 \mathrm{~mm}$ NMR tubes as freshly prepared $\mathrm{CDCl}_{3}$ solutions on a Bruker DPX-300 spectrometer operating at $300,75.5$ and $111.9 \mathrm{MHz}$, respectively. Spectra were referenced with internal chloroform peak $\left({ }^{*} 7.26\right.$ for ${ }^{1} \mathrm{H}$ and 77.0 for ${ }^{13} \mathrm{C}$ ). Molecular weight measurements were carried out by elevation in boiling point method using Beckman's thermometer fitted in a class assembly in anhydrous benzene. The instrument was calibrated using samples of known molecular weight like naphthalene/benzophenone/benzil in anhydrous benzene ( $M=$ $1000 . K_{b} \cdot w / \Delta T_{b}, W$, where $M=$ molecular weight, $w=$ weight of solute in gms., $K_{b}=$ molar elevation constant, $W=$ weight of solvents in gms., $\Delta T_{b}=$ elevation in boiling point).

\section{Preparation of $\mathrm{Et}_{2} \mathrm{Al}\left\{\mathrm{O}-\left(\mathrm{CH}_{2}\right)_{3}-\mathrm{NH}_{2}\right\}$}

A solution of $\mathrm{Et}_{3} \mathrm{Al} . \mathrm{Et}_{2} \mathrm{O}(1.19 \mathrm{gm}, 6.32 \mathrm{mmol})$ in $20 \mathrm{ml}$ of anhydrous diethylether was slowly added to an ether solution of $\mathrm{HO}\left(\mathrm{CH}_{2}\right)_{3} \mathrm{NH}_{2}(0.48 \mathrm{gm}, 6.35 \mathrm{mmol})$ under argon atmosphere. The reaction mixture was stirred at room temperature for $4 \mathrm{~h}$. The solvents were evaporated under vacuum and the product was washed $(2 \times 10 \mathrm{ml})$ with $n$-hexane. The compound was dried under vacuum to give a white solid (yield $96 \%)$. This was recrystallized from a mixture of dichloromethane and $n$-hexane $(7: 1)$.

\section{Preparation of EtAl $\left\{\mathrm{O}-\left(\mathrm{CH}_{2}\right)_{2}-\mathrm{NH}_{2}\right\}_{2}$}

A solution of $\mathrm{Et}_{3} \mathrm{Al}_{\mathrm{E}} \mathrm{Et}_{2} \mathrm{O}(2.13 \mathrm{gm}, 11.31 \mathrm{mmol})$ in $20 \mathrm{ml}$ of anhydrous diethylether was slowly added to an ether solution of $\mathrm{HO}\left(\mathrm{CH}_{2}\right)_{2} \mathrm{NH}_{2}(1.38 \mathrm{gm}, 22.59 \mathrm{mmol})$ under argon atmosphere. The reaction mixture was stirred at room temperature for $4 \mathrm{~h}$. The solvents were evaporated under vacuum and the product was washed $(2 \times 10 \mathrm{ml})$ with $\mathrm{n}$-hexane. The compound was dried under vacuum to give a white solid (yield $98 \%)$. This was recrystallized from a mixture of dichloromethane and $n$-hexane (7:1). All other complexes were prepared by using a similar route and their physical and analytical data are summarized in Table 1. 


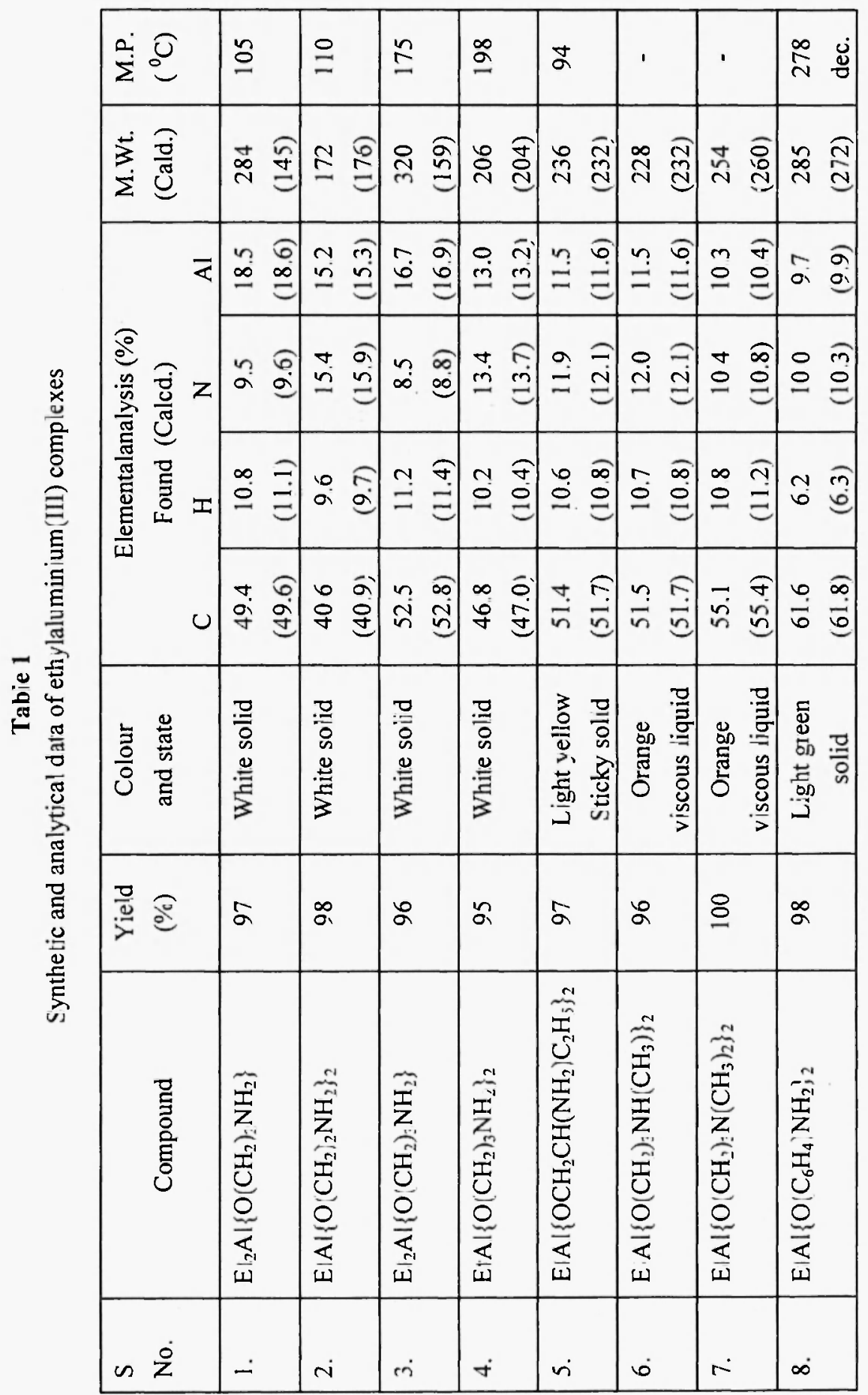




\section{RESULTS AND DISCUSSION}

All the above reactions were carried out under strictly anhydrous and inert atmosphere. Reactions of $\mathrm{Et}_{3} \mathrm{Al}$.Et ${ }_{2} \mathrm{O}$ with aminoalcohols (HO-R-NR $\mathrm{R}^{2}$ ) in $1: 1$ as well as $1: 2$ molar ratio in diethylether afforded products of the type $\left[\mathrm{Et}_{2} \mathrm{Al}\left(\mathrm{O}-\mathrm{R}-\mathrm{NR}{ }^{1} \mathrm{R}^{2}\right)\right]$ and $\left[\mathrm{EtAl}\left(\mathrm{O}-\mathrm{R}-\mathrm{NR} \mathrm{R}^{1} \mathrm{R}^{2}\right)_{2}\right]$. The general reaction may be illustrated schematically as:

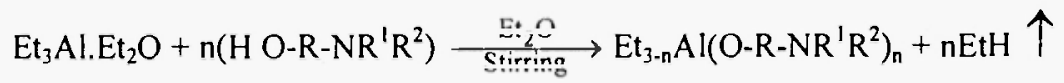

where $\left.\mathrm{n}=1,\left[\mathrm{R}=-\mathrm{CH}_{2}\right)_{2}, \mathrm{R}^{1}=\mathrm{R}^{2}=\mathrm{H} ; \mathrm{R}=-\left(\mathrm{CH}_{2}\right)_{3}, \mathrm{R}^{1}=\mathrm{R}^{2}=\mathrm{H}\right]$

where $n=2,\left[R=-\mathrm{CH}_{2}\right)_{2}, \mathrm{R}^{\prime}=\mathrm{R}^{2}=\mathrm{H} ; \mathrm{R}=-\left(\mathrm{CH}_{2}\right)_{3}, \mathrm{R}^{1}=\mathrm{R}^{2}=\mathrm{H} ; \mathrm{R}=-\mathrm{CH}_{2} \mathrm{CH}\left(\mathrm{CH}_{2} \mathrm{CH}_{3}\right), \mathrm{R}^{\prime}=\mathrm{R}^{2}=\mathrm{H}$;

$$
\left.\mathrm{R}=-\left(\mathrm{CH}_{2}\right)_{3}, \mathrm{R}^{\prime}=\mathrm{H}, \mathrm{R}^{2}=\mathrm{CH}_{3} ; \mathrm{R}=-\left(\mathrm{CH}_{2}\right)_{3}, \mathrm{R}^{1}=\mathrm{R}^{2}=\mathrm{CH}_{3} ; \mathrm{R}=-\mathrm{C}_{6} \mathrm{H}_{4}, \mathrm{R}^{1}=\mathrm{R}^{2}=\mathrm{H}\right]
$$

All the above compounds are white, yellow or light green solids or paste (Table I), and are soluble in common organic solvents. These compounds were purified by recrystallization from a mixture of dichloromethane and $n$-hexane. Molecular weight measurements indicate the monomeric nature of 1:2 complexes and dimeric nature of $1: 1$ complexes in refluxing benzene.

\section{Table II}

\begin{tabular}{|c|c|c|c|c|c|c|c|c|}
\hline S. & Compound & Amin & Ikanolate & Moiety & & & & \\
\hline No & & $v \mathrm{C}-\mathrm{N}$ & $v \mathrm{C}-\mathrm{O}$ & $v \mathrm{~N}-\mathrm{H}$ & $v A \mid-C$ & $\vee A I-O$ & $\nu A \mid-N$ & $v \mathrm{Al}-\mathrm{O}-\mathrm{Al}$ \\
\hline 1. & $\mathrm{Et}_{2} \mathrm{Al}\left\{\mathrm{O}\left(\mathrm{CH}_{2}\right)_{2} \mathrm{NH}_{2}\right\}$ & $1075 \mathrm{~m}$ & $1225 w$ & $2900 \mathrm{vs}$ & $600 w$ & $710 \mathrm{~m}$ & $660 w$ & $=$ \\
\hline 2. & $\mathrm{EtAl}\left\{\mathrm{O}\left(\mathrm{CH}_{2}\right)_{2} \mathrm{NH}_{2}\right\}_{2}$ & $1060 \mathrm{~s}$ & $1200 w$ & $2890 \mathrm{vs}$ & $590 w$ & $695 w$ & $648 w$ & - \\
\hline 3. & $\mathrm{Et}_{2} \mathrm{Al}\left\{\mathrm{O}\left(\mathrm{CH}_{2}\right)_{3} \mathrm{NH}_{2}\right\}$ & $1075 \mathrm{~m}$ & $1270 w$ & $2900 v s$ & $600 \mathrm{~m}$ & $710 \mathrm{~m}$ & $620 w$ & $820 w$ \\
\hline 4. & $\mathrm{EtAl}\left\{\mathrm{O}\left(\mathrm{CH}_{2}\right)_{3} \mathrm{NH}_{2}\right\}_{2}$ & $1066 \mathrm{~m}$ & $1200 w$ & $2890 v s$ & $616 w$ & $725 \mathrm{~m}$ & $674 w$ & - \\
\hline 5. & $\mathrm{EtAl}\left\{\mathrm{OCH}_{2} \mathrm{CH}\left(\mathrm{NH}_{2}\right) \mathrm{C}_{2} \mathrm{H}_{5}\right\}_{2}$ & $1080 w$ & $1250 w$ & $2916 \mathrm{vs}$ & $566 w$ & $716 \mathrm{~m}$ & $649 w$ & - \\
\hline 6. & $\operatorname{EtAl}\left\{\mathrm{O}\left(\mathrm{CH}_{2}\right)_{3} \mathrm{NH}\left(\mathrm{CH}_{3}\right)\right\}_{2}$ & $1100 \mathrm{~s}$ & $1260 \mathrm{w}$ & $2950 \mathrm{vs}$ & $550 w$ & $710 \mathrm{~m}$ & $660 w$ & - \\
\hline 7. & $\mathrm{EtAl}\left\{\mathrm{O}\left(\mathrm{CH}_{2}\right)_{3} \mathrm{~N}\left(\mathrm{CH}_{3}\right)_{2}\right\}_{2}$ & $1050 \mathrm{~s}$ & $1240 w$ & $2916 \mathrm{vs}$ & $656 \mathrm{~m}$ & $708 w$ & $675 w$ & - \\
\hline 8. & $\mathrm{EtAl}\left\{\mathrm{O}\left(\mathrm{C}_{6} \mathrm{H}_{4}\right) \mathrm{NH}_{2}\right\}_{2}$ & $1083 w$ & $1250 w$ & $2900 \mathrm{vs}$ & $600 w$ & $708 w$ & $658 w$ & - \\
\hline
\end{tabular}

Some relevant IR spectral data of ethylaluminium(III) complexes. 


\section{IR Spectra}

A tentative assignment of the important IR bands has been made and is summarized in Table II. Broad stretching vibrations at $-3650 \mathrm{~cm}^{-1}$ due to $-\mathrm{OH}$ group of the free aminoalcohols disappeared in the IR spectra of the above derivatives, suggesting the deprotonation of $-\mathrm{OH}$ group and formation of an $\mathrm{Al}-\mathrm{O}$ bond. Formation of an Al-O /10,11,17, 18/ bond is further supported by the appearance of a weak to medium intensity band in the region $695-725 \mathrm{~cm}^{-1}$. The appearance of $v \mathrm{~N}-\mathrm{H}$ as well as $v \mathrm{C}-\mathrm{N}$ stretching frequencies at lower wave numbers, as compared to the free ligand moieties, indicates the coordination of aluminium to the nitrogen atom of the ligand. This was further confirmed by the appearance of a new weak to medium intensity band in the region $620-675 \mathrm{~cm}^{-1}$, which may be assigned to $\vee \mathrm{Al}-\mathrm{N}$ mode $19,11 \%$. The weak intensity band in the region $550-656 \mathrm{~cm}^{-1}$ was assigned to $\vee$ Al-C. In 1:1 complex (3) an additional weak band at $820 \mathrm{~cm}^{-1}$ has also been observed and assigned as $v \mathrm{Al}-\mathrm{O}-\mathrm{Al}$ mode $/ 10,11,23 /$, but complex (1) does not show such stretching.

\section{${ }^{1}$ H NMR Spectra}

A comparison of the spectra of the free aminoalcohols with the spectra of the corresponding derivatives shows the absence of $-\mathrm{OH}$ signals, indicating deprotonation of the hydroxy group of the aminoalcohols and formation of Al-O bond. 'H NMR spectra of these complexes exhibit characteristic peaks and peak multiplicities for Et-Al and ligand protons /19-21\%. In the ${ }^{1} \mathrm{H}$ NMR spectra of the complexes, the $\mathrm{CH}_{2}$ and $\mathrm{CH}_{3}$ protons of EtAI group appear in the range $\delta 0.06-0.98 \mathrm{ppm}$ and $\delta 1.05-1.39 \mathrm{ppm}$, respectively. The $\mathrm{O}-\mathrm{CH}$ as well as $\mathrm{CH}_{2} \mathrm{~N}$ proton resonances of ligands are shielded on complexation. Shielding effect is greater in 1:2 complexes as compared to $1: 1$ complexes. Other resonances are almost unaffected and appear at their expected positions (Table III).

\section{${ }^{13}$ C NMR Spectra}

In the ${ }^{13} \mathrm{C}$ NMR spectra of the complexes the $\mathrm{CH}_{2}$ and $\mathrm{CH}_{3}$ carbon signals of EtAl group appear in the range $\delta \quad 0.55-1.11 \mathrm{ppm}$ and $\delta 2.92-18.3 \mathrm{ppm}$, respectively. The $\mathrm{C}-\mathrm{N}$ carbon resonances of ligands are shielded on complexation as compared to the free ligand, which suggests that there may be coordination of aluminium through nitrogen atom as evinced by IR spectra. Other resonances are unchanged, except $-\mathrm{O}-\mathrm{C}$, which is slightly shielded.

\section{${ }^{27}$ AI NMR Spectra}

Coordination behavior of the $E t_{2} A I\left\{O-R-N R^{1} R^{2}\right\}$ type of the complexes has also been investigated long ago /23/ and two possible structures had been proposed for dinuclear diethyl allong ago /23/ and two possible structures had been proposed for dinuclear diethyl aluminium complexes containing tetra-coordination around aluminium(III) atom on the basis of IR and ${ }^{1} \mathrm{H}$ NMR studies. However, no suitable ${ }^{27} \mathrm{Al}$ NMR spectra and no crystal structure determinations were reported. During the course of the present investigation we 
Table III

$\operatorname{NMR}\left({ }^{1} \mathrm{H},{ }^{13} \mathrm{C} \&{ }^{27} \mathrm{Al}\right)$ spectral data of ethylaluminium(III) complexes

\begin{tabular}{|c|c|c|c|c|c|}
\hline \multirow{2}{*}{$\begin{array}{l}\text { Compound } \\
\text { No.* }\end{array}$} & \multicolumn{2}{|c|}{${ }^{1} \mathrm{H}$ NMR } & \multicolumn{2}{|c|}{${ }^{13} \mathrm{C}$ NMR } & \multirow{2}{*}{$\begin{array}{l}{ }^{27} \mathrm{Al} \\
\mathrm{NMR}\end{array}$} \\
\hline & Ethyl moiety & $\begin{array}{l}\text { Aminoalkanolate } \\
\text { moiety }\end{array}$ & Ethyl moiety & $\begin{array}{l}\text { Aminoalkanolate } \\
\text { moiety }\end{array}$ & \\
\hline 1. & $\begin{array}{l}0.98 \text { br }\left(\mathrm{CH}_{2}\right) \\
1.10 \text { t }\left(\mathrm{C}_{3}\right)\end{array}$ & $\begin{array}{l}1.27 \mathrm{br}\left(\mathrm{NH}_{2}\right) \\
3.62 \mathrm{~m}\left(\mathrm{OCH}_{2} \mathrm{CH}_{2}\right) \\
3.77 \mathrm{br}\left(\mathrm{OCH}_{2}\right)\end{array}$ & $\begin{array}{l}0.92\left(\mathrm{CH}_{2}\right) \\
10.2\left(\mathrm{CH}_{3}\right)\end{array}$ & $\begin{array}{l}58.1\left(\mathrm{OCH}_{2} \mathrm{CH}_{2}\right) \\
65.0\left(\mathrm{OCH}_{2}\right)\end{array}$ & 67.3 \\
\hline 2. & $\begin{array}{l}0.98 \mathrm{q}\left(\mathrm{CH}_{2}\right) \\
1.21 \mathrm{t}\left(\mathrm{C}_{3}\right)\end{array}$ & $\begin{array}{l}1.32 \mathrm{br}\left(\mathrm{NH}_{2}\right) \\
3.57 \mathrm{~m}\left(\mathrm{OCH}_{2} \mathrm{CH}_{2}\right) \\
3.67 \mathrm{t}\left(\mathrm{OCH}_{2}\right)\end{array}$ & $\begin{array}{l}0.89\left(\mathrm{CH}_{2}\right) \\
9.21\left(\underline{\mathrm{CH}}_{3}\right)\end{array}$ & $\begin{array}{l}57.7\left(\mathrm{OCH}_{2} \mathrm{CH}_{2}\right) \\
64.3\left(\mathrm{OCH}_{2}\right)\end{array}$ & 69.8 \\
\hline 3. & $\begin{array}{l}0.09 \mathrm{br} \quad\left(\mathrm{CH}_{2}\right) \\
1.10 \mathrm{t}\left(\mathrm{CH}_{3}\right)\end{array}$ & $\begin{array}{l}0.88 \mathrm{~s}\left(\mathrm{NH}_{2}\right) \\
1.64 \mathrm{br}\left(\mathrm{C}_{2} \mathrm{NH}_{2}\right) \\
3.01 \mathrm{br}\left(\mathrm{OCH}_{2} \mathrm{CH}_{2}\right) \\
3.80 \mathrm{br}\left(\mathrm{OCH}_{2}\right)\end{array}$ & $\begin{array}{l}0.81\left(\mathrm{CH}_{2}\right) \\
10.3\left(\mathrm{CH}_{3}\right)\end{array}$ & $\begin{array}{l}41.6\left(\mathrm{CH}_{2} \mathrm{NH}_{2}\right) ; \\
57.6\left(\mathrm{OCH}_{2} \mathrm{CH}_{2}\right) ; \\
64.2\left(\mathrm{OCH}_{2}\right)\end{array}$ & 69.8 \\
\hline 4. & $\begin{array}{l}0.09 \mathrm{~m}\left(\mathrm{CH}_{2}\right) \\
1.14 \mathrm{~m}\left(\mathrm{CH}_{3}\right)\end{array}$ & $\begin{array}{l}0.88 \mathrm{~s}\left(\mathrm{NH}_{2}\right) \\
1.58 \mathrm{br}\left(\mathrm{CH}_{2} \mathrm{NH}_{2}\right) \\
3.01 \mathrm{br}\left(\mathrm{OCH}_{2} \mathrm{CH}_{2}\right) \\
3.77 \mathrm{br}\left(\mathrm{OCH}_{2}\right)\end{array}$ & $\begin{array}{l}0.81\left(\underline{\mathrm{CH}}_{2}\right) ; \\
18.3\left(\underline{\mathrm{CH}}_{3}\right)\end{array}$ & $\begin{array}{l}41.7\left(\mathrm{CH}_{2} \mathrm{NH}_{2}\right) ; \\
57.8\left(\mathrm{OCH}_{2} \mathrm{CH}_{2}\right) ; \\
63.6\left(\mathrm{OCH}_{2}\right)\end{array}$ & 70.0 \\
\hline 5. & $\begin{array}{l}0.09 \text { br }\left(\mathrm{CH}_{2}\right) \\
1.26 \mathrm{t}\left(\mathrm{CH}_{3}\right)\end{array}$ & $\begin{array}{l}0.95 \mathrm{~s}\left(\mathrm{NH}_{2}\right) ; \\
2.72 \mathrm{br} \\
\left\{\mathrm{CH}\left(\mathrm{NH}_{2}\right) \mathrm{CH}_{2} \mathrm{CH}_{3}\right\} ; \\
3.32 \mathrm{~m}\left(\mathrm{OCH}_{2} \mathrm{CH}\right) ; \\
3.51-3.74 \mathrm{~m}\left(\mathrm{OCH}_{2}\right)\end{array}$ & $\begin{array}{l}0.55\left(\mathrm{CH}_{2}\right) \\
10.2\left(\mathrm{CH}_{3}\right)\end{array}$ & $\begin{array}{l}27.3\left(\mathrm{CHCH}_{2} \mathrm{CH}_{3}\right) ; \\
54.2\left(\mathrm{OCH}_{2} \mathrm{CH}\right) ; \\
57.8\left(\mathrm{CHCH}_{2} \mathrm{CH}_{3}\right) ; \\
66.5\left(\mathrm{OCH}_{2}\right)\end{array}$ & 70.4 \\
\hline 6. & $\begin{array}{l}0.77 \mathrm{~m}\left(\mathrm{CH}_{2}\right) \\
1.05 \mathrm{t}\left(\mathrm{CH}_{3}\right)\end{array}$ & $\begin{array}{l}1.10 \text { br }(\mathrm{NH}) \\
2.33 \text { br }\left\{\mathrm{NH}\left(\mathrm{CH}_{3}\right)\right\} \\
2.58 \text { br }\left(\mathrm{CH}_{2} \mathrm{NH}\right) \\
3.64 \mathrm{br}\left(\mathrm{OCH}_{2} \mathrm{CH}_{2}\right)\end{array}$ & $\begin{array}{l}1.08\left(\mathrm{CH}_{2}\right) \\
18.5\left(\mathrm{CH}_{3}\right)\end{array}$ & $\begin{array}{l}36.3\left\{\mathrm{NH}\left(\mathrm{CH}_{3}\right) ;\right. \\
56.6 \\
\left(\mathrm{OCH}_{2} \mathrm{CH}_{2} \mathrm{CH}_{2}\right) ; \\
57.5\left(\mathrm{OCH}_{2} \mathrm{CH}_{2}\right) ; \\
61.2\left(\mathrm{OCH}_{2}\right)\end{array}$ & 71.1 \\
\hline 7. & $\begin{array}{l}0.06 \text { br }\left(\mathrm{CH}_{2}\right) ; \\
1.26 \text { br }\left(\mathrm{CH}_{3}\right)\end{array}$ & $\begin{array}{l}1.68-1.99 \mathrm{~m} \\
\left(\mathrm{CH}_{2} \mathrm{CH}_{2} \mathrm{~N}\right) \\
2.31 \mathrm{br}\left\{\mathrm{N}\left(\mathrm{CH}_{3}\right)_{2}\right\} \\
3.80 \mathrm{br}\left(\mathrm{OCH}_{2}\right)\end{array}$ & $\begin{array}{l}1.11\left(\mathrm{CH}_{2}\right) \\
18.0\left(\mathrm{CH}_{3}\right)\end{array}$ & $\begin{array}{l}45.4\left\{\mathrm{~N}\left(\mathrm{CH}_{3}\right)_{2}\right\} ; \\
56.7 \\
\left(\mathrm{OCH}_{2} \mathrm{CH}_{2} \mathrm{CH}_{2}\right) ; \\
61.9\left(\mathrm{OCH}_{2}\right)\end{array}$ & 67.9 \\
\hline 8. & $\begin{array}{l}0.22 \text { br }\left(\mathrm{CH}_{2}\right) ; \\
1.39 \mathrm{t}\left(\mathrm{CH}_{3}\right)\end{array}$ & $\begin{array}{l}1.07 \mathrm{~s}\left(\mathrm{NH}_{2}\right) ; \\
6.75-7.35 \mathrm{~m}\left(\mathrm{OC}_{6} \underline{\mathrm{H}}_{4}\right)\end{array}$ & $\begin{array}{l}0.83\left(\mathrm{CH}_{2}\right) \\
13.9\left(\mathrm{CH}_{3}\right)\end{array}$ & $\begin{array}{l}124.0,124.8,128.3 \\
129.3,131.2\left(\mathrm{C}_{6} \mathrm{H}_{4}\right)\end{array}$ & 71.0 \\
\hline
\end{tabular}

${ }^{*}$ Compound Nos. as in Table II 
carried out the ${ }^{27} \mathrm{Al}$ NMR spectra of the above types of complexes, which exhibit a broad signal at $\delta 67.3$ $71.2 \mathrm{ppm}$. They exclude the possibility of tetra-coordination geometry, and suggest a penta-coordination around the aluminiun(III) atom $/ 20$ - $22 \%$.

\section{CONCLUSION}

Although it is difficult to comment on the structural aspects of these derivatives without single crystal Xray studies of at least one representative compound, yet in view of the above studies on the dimeric nature of $1: 1$ complexes and monomeric nature of $1: 2$ complexes, the following tentative structures may be proposed for these types of derivatives:

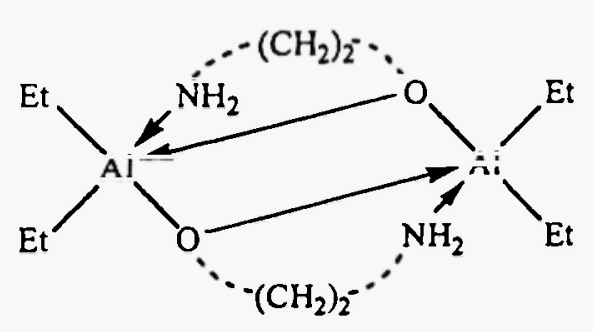

(a)<smiles>CCCN[Al](N)(CC)OCC</smiles>

(b)

Fig. 2: Proposed structure of $\mathrm{Et}_{2}\left\{\mathrm{O}-\left(\mathrm{CH}_{2}\right)_{2}-\mathrm{NH}_{2}\right\}$ (a) and $\left.\mathrm{Et}_{2} \mathrm{Al}\{)-\left(\mathrm{CH}_{2}\right)_{3}-\mathrm{NH}_{2}\right\}$ (b)<smiles></smiles>

Fig. 3: Proposed structure of EtAI[O-R-NR' $\left.\mathrm{R}^{2}\right]_{2}$.

$\left[\mathrm{R}=-\mathrm{CH}_{2}\right)_{2}, \mathrm{R}^{\prime}=\mathrm{R}^{2}=\mathrm{H} ; \mathrm{R}=-\left(\mathrm{CH}_{2}\right)_{3}, \mathrm{R}^{1}=\mathrm{R}^{2}=\mathrm{H} ; \mathrm{R}=-\mathrm{CH}_{2} \mathrm{CH}\left(\mathrm{CH}_{2} \mathrm{CH}_{3}\right), \mathrm{R}^{\prime}=\mathrm{R}^{2}=\mathrm{H} ; \mathrm{R}=-\left(\mathrm{CH}_{2}\right)_{3}$, $\left.\mathrm{R}^{1}=\mathrm{H}, \mathrm{R}^{2}=\mathrm{CH}_{3} ; \mathrm{R}=-\left(\mathrm{CH}_{2}\right)_{3}, \mathrm{R}^{1}=\mathrm{R}^{2}=\mathrm{CH}_{3} ; \mathrm{R}=-\mathrm{C}_{6} \mathrm{H}_{4}, \mathrm{R}^{1}=\mathrm{R}^{2}=\mathrm{H}\right]$

\section{ACKNOWLEDGEMENTS}

One of the authors (A.K. Jain) is grateful to S.A.P., Department of Chemistry, University of Rajasthan, Jaipur for the award of Junior Research Fellowship, and another (A.G.) is thankful to CSIR, New Delhi for the award of a Senior Research Fellowship to her. 


\section{REFERENCES}

1. J. Storre, C. Schnitter, H.W. Roesky, H.-G. Schmidt, M. Noltemeyer, R. Fluscher and D. Stalke, J. Am. Chem. Soc., 119, 7505 (1997).

2. M.D. Healy, J.W. Ziller and A.R. Barron, J. Am. Chem. Soc., 112, 2949 (1990).

3. C. Cui, H.W. Roesky, M. Noltemeyer, M.F. Lappert, H.-G. Schmidt and H. Hao, Organometallics, 18, 2256 (1999).

4. G.S. Hair, S.L. Battle, A. Decken, A.H. Cowley and R.A. Jones, Inorg. Chem., 39, 27 (2000).

5. W. Zheng, H. Hohmeister, N.C. Mosch-Zanetti, H.W. Roesky, M. Noltemeyer and H.-G. Schmidt, Inorg. Chem., 40, 2363 (2001).

6. W. Uhl, J. Molter and B. Neumuller, Inorg Chem., 40, 2011 (2001).

7. P.L. Gurian, L.K. Cheatham, J.W. Ziller and A.R. Barron, J. Chem. Soc. Dalton Trans., 1991, 1449.

8. J. Lewinski, J. Zachara, B. Mank and S. Pasynkiewcz, J. Organomet. Chem., 454, 5 (1993).

9. A. Dhammani, R. Bohra and R.C. Mehrotra, Polyhnedron, 15, 733 (1996).

10. N. Sharma, R.K. Sharma and R.Bohra, Main Group Met. Chem., 24, 781 (2001).

11. N. Sharma, R.K. Sharma, R. Bohra, J.E. Drake, M.B. Hursthouse and M.E. Light, J. Chem. Soc. Dalton Trans., 2002, 1631.

12. N. Sharma, R.K. Sharma and R. Bohra, J. Chem. Research, in press (2002).

13. S. Nagar, R. Bohra and R.C. Mehrotra, Main Group Met. Chem., 25, 277 (2002).

14. N. Sharma, A.K. Jain, R.K. Sharma, R. Bohra, J.E. Drake, M.B. Hursthouse and M.E. Light, J. Chem. Soc. Dalton Trans., 2003 (communicated).

15. N. Aunder and U. Klingebiel, Synthetic Methods of Organometallic and Inorganic Chemistry, Georg Thieme Verlag, Stuttgart-New York, 2, 1996; p. 310.

16. A.I. Vogel, Textbook Quantitative Chemical Analysis, Longmans, London (Vth Edition), 1989.

17. A. Singh, A.K. Rai and R.C. Mehrotra, Indian .J. Chem., 11, 478 (1973).

18. R. Bohra, A. Dhammani, R.K. Sharma and R.C. Mehrotra, Synth. React. Inorg. Met. Org. Chem., 36, $681(2001)$.

19. V.L. Goedken, H. Ito and T. Ito, J. Chem. Soc.Chem. Commun., 1984, 1453.

20. S.J. Dzugan and V.L. Goedken, Inorg. Chem., 25, 2858 (1986).

21. Z. Jiang, L.V. Interrante, D. Kwon, F.S. Tham and R. Kullnig, Inorg. Chem., 30, 995 (1991).

22. W. Ziemkowska, S. Pasynkiewicz and T. Skrok, Main Group Met. Chem., 21, 105 (1998).

23. T.G. Hurley, M.A. Robinson, J.A. Scruggs and S.I. Trotz, Inorg. Chem., 6, 1310 (1967). 